\title{
Effects of $\left(\mathrm{Mg}_{1 / 3} \mathrm{Sb}_{2 / 3}\right)^{4+}$ substitution on the structure and microwave dielectric properties of $\mathrm{Ce}_{2} \mathrm{Zr}_{3}\left(\mathrm{MoO}_{4}\right)_{9}$ ceramics
}

\author{
$\mathrm{Xu} \mathrm{ZHOU}^{a}$, Lintao $\mathrm{LIU}^{a}$, Jiajia $\mathrm{SUN}^{b}$, Ningkang ZHANG ${ }^{b}$, \\ Huazhang $\mathrm{SUN}^{b}$, Haitao $\mathrm{WU}^{a, *}$, Wenhong $\mathrm{TAO}^{b, *}$ \\ ${ }^{a}$ School of Environmental and Material Engineering, Yantai University, Yantai 264005, China \\ ${ }^{b}$ School of Materials Science and Engineering, University of Jinan, Jinan 250022, China
}

Received: November 2, 2020; Revised: January 19, 2021; Accepted: March 6, 2021

(c) The Author(s) 2021.

\begin{abstract}
Ce}_{2}\left[\mathrm{Zr}_{1-x}\left(\mathrm{Mg}_{1 / 3} \mathrm{Sb}_{2 / 3}\right)_{x}\right]_{3}\left(\mathrm{MoO}_{4}\right)_{9}(0.02 \leqslant x \leqslant 0.10)$ ceramics were prepared by the traditional solid-state method. A single phase, belonging to the space group of $R \overline{3} c$, was detected by using X-ray diffraction at the sintering temperatures ranging from 700 to $850{ }^{\circ} \mathrm{C}$. The microstructures of samples were examined by applying scanning electron microscopy (SEM). The crystal structure refinement of these samples was investigated in detail by performing the Rietveld refinement method. The intrinsic properties were calculated and explored via far-infrared reflectivity spectroscopy. The correlations between the chemical bond parameters and microwave dielectric properties were calculated and analyzed by Phillips-van Vechten-Levine (P-V-L) theory. $\mathrm{Ce}_{2}\left[\mathrm{Zr}_{0.94}\left(\mathrm{Mg}_{1 / 3} \mathrm{Sb}_{2 / 3}\right)_{0.06}\right]_{3}\left(\mathrm{MoO}_{4}\right)_{9}$ ceramics with excellent dielectric properties were sintered at $725^{\circ} \mathrm{C}$ for $6 \mathrm{~h}\left(\varepsilon_{\mathrm{r}}=10.37, Q \times f=71,748 \mathrm{GHz}\right.$, and $\tau_{\mathrm{f}}=-13.6 \mathrm{ppm} /{ }^{\circ} \mathrm{C}, \varepsilon_{\mathrm{r}}$ is the dielectric constant, $Q \times f$ is the quality factor, and $\tau_{\mathrm{f}}$ is the temperature coefficient of resonant frequency).
\end{abstract}

Keywords: crystal structure; Phillips-van Vechten-Levine (P-V-L) theory; microwave dielectric property; $\left(\mathrm{Mg}_{1 / 3} \mathrm{Sb}_{2 / 3}\right)$ doping

\section{Introduction}

It is well-known that dielectric materials have developed rapidly in the past decades. Microwave dielectric ceramics have sprung up in the communication industry and received widely attentions. It is required to have a high-quality factor $(Q \times f)$, a moderate dielectric constant $\left(\varepsilon_{\mathrm{r}}\right)$, and a near-zero temperature coefficient of resonant frequency $\left(\tau_{\mathrm{f}}\right)$ to meet the demands of applications [1,2]. Recently, researchers focused on

\footnotetext{
* Corresponding authors.

E-mail: H.Wu,mse_wuht@ujn.edu.cn;

W. Tao,mse_taowh@ujn.edu.cn
}

novel microwave dielectric ceramics. At the same time, some researchers have widely investigated the substitution of cationic and composite ceramics to improve the dielectric properties of microwave dielectric materials [3-5]. In addition, high cost limits the application of these ceramics, and consequently it is required to reduce their sintering temperatures. The low temperature co-fired ceramic (LTCC) [6-8] technology has become a common method due to its simplicity and high efficiency. Hence, LTCC technology is becoming more and more important in practical applications.

In recent years, Mo-based microwave dielectric ceramics have been studied in depth as shown in Table 1 [9-13]. Many microwave dielectric ceramic systems 
Table 1 Summarized microwave dielectric properties of Mo-based microwave dielectric ceramics

\begin{tabular}{|c|c|c|c|c|c|}
\hline Material & $\begin{array}{c}\text { Sintering } \\
\text { temperature }\left({ }^{\circ} \mathrm{C}\right)\end{array}$ & $\varepsilon_{\mathrm{r}}$ & $Q \times f(\mathrm{GHz})$ & $\tau_{\mathrm{f}}\left(\mathrm{ppm} /{ }^{\circ} \mathrm{C}\right)$ & Ref. \\
\hline $\mathrm{Sm}_{2} \mathrm{Zr}_{3}\left(\mathrm{MoO}_{4}\right)_{9}$ & 875 & 11.0 & 74,012 & -45.3 & [9] \\
\hline $\mathrm{Nd}_{2} \mathrm{Zr}_{3}\left(\mathrm{MoO}_{4}\right)_{9}$ & 850 & 10.8 & 58,942 & -40.9 & [9] \\
\hline $\mathrm{Eu}_{2} \mathrm{Zr}_{3}\left(\mathrm{MoO}_{4}\right)_{9}$ & 600 & 10.75 & 74,900 & -8.88 & {$[10]$} \\
\hline $\mathrm{La}_{2} \mathrm{Zr}_{3}\left(\mathrm{MoO}_{4}\right)_{9}$ & 650 & 10.8 & 61,790 & -29.1 & {$[11]$} \\
\hline $\mathrm{La}_{2}\left(\mathrm{Zr}_{0.92} \mathrm{Ti}_{0.08}\right)_{3}\left(\mathrm{MoO}_{4}\right)_{9}$ & 750 & 10.33 & 80,658 & 3.48 & [11] \\
\hline $\mathrm{Ce}_{2} \mathrm{Zr}_{3}\left(\mathrm{MoO}_{4}\right)_{9}$ & 575 & 10.69 & 19,062 & -1.29 & {$[12]$} \\
\hline $\mathrm{Ce}_{2}\left(\mathrm{Zr}_{0.92} \mathrm{Ti}_{0.08}\right)_{3}\left(\mathrm{MoO}_{4}\right)_{9}$ & 775 & 11.28 & 84,200 & -7.86 & [13] \\
\hline $\mathrm{Ce}_{2}\left[\mathrm{Zr}_{0.94}\left(\mathrm{Mg}_{1 / 3} \mathrm{Sb}_{2 / 3}\right)_{0.06}\right]_{3}\left(\mathrm{MoO}_{4}\right)_{9}$ & 725 & 10.37 & 71,748 & -13.6 & This work \\
\hline
\end{tabular}

have been developed, but their properties are not optimistic. The performance $(Q \times f=19,062 \mathrm{GHz})$ of $\mathrm{Ce}_{2} \mathrm{Zr}_{3}\left(\mathrm{MoO}_{4}\right)_{9}$ ceramic was investigated [12]. In order to improve $Q \times f$ of $\mathrm{Ce}_{2} \mathrm{Zr}_{3}\left(\mathrm{MoO}_{4}\right)_{9}$ ceramics, doping $\left(\mathrm{Mg}_{1 / 3} \mathrm{Sb}_{2 / 3}\right)^{4+}$ at $\mathrm{Zr}$-sites was reported in this work. The crystal structure and the sintering behavior of samples were discussed in detail. Also, the relationship between the dielectric properties and the structure of samples was explored scientifically by far infrared reflectivity spectrum and the Phillips-van Vechten-Levine ( $\mathrm{P}-\mathrm{V}-\mathrm{L})$ theory.

\section{Experimental}

Highly pure powders of $\mathrm{CeO}_{2}, \mathrm{ZrO}_{2}, \mathrm{MoO}_{3}, \mathrm{MgO}$, and $\mathrm{Sb}_{2} \mathrm{O}_{5}$ were weighed accurately based on the stoichiometric composition of $\mathrm{Ce}_{2}\left[\mathrm{Zr}_{1-x}\left(\mathrm{Mg}_{1 / 3} \mathrm{Sb}_{2 / 3}\right)_{x}\right]_{3}\left(\mathrm{MoO}_{4}\right)_{9}$ $(0.02 \leqslant x \leqslant 0.10)$. The mixed powders were continuously rotated for $24 \mathrm{~h}$ with ethanol media and $\mathrm{ZrO}_{2}$ balls. Mixtures were oven-dried at $80{ }^{\circ} \mathrm{C}$ and pre-sintered at $700{ }^{\circ} \mathrm{C}$ for $2 \mathrm{~h}$, and after that, ball milled and dried again under the same condition as above. Subsequently, the combination of powders and $10 \mathrm{wt} \%$ paraffin passed through a 60 -mesh sieve, and a certain size of the cylinders (length $\approx 6 \mathrm{~mm}$, diameter $\approx$ $10 \mathrm{~mm}$ ) was pressed at $200 \mathrm{MPa}$. Those pressed cylinders were sintered from 700 to $850{ }^{\circ} \mathrm{C}$ for $6 \mathrm{~h}$.

Phase identification of sintered pellets was analyzed using a X-ray diffraction (D8 Advance, Bruker Co., Germany) with $\mathrm{Cu} K \alpha$ radiation and refined lattice parameters were obtained using a FULLPROF program to explore structure. The surface microstructures of specimens were observed by using a QUANTA 250FEG type scanning electron microscope (SEM, FEI Co., USA), equipped with the energy dispersive spectrometer (EDS). The apparent densities of specimens were analyzed using Archimedes method. The infrared reflectivity spectrum was recorded by a Bruker IFS66v FTIR spectrometer at National Synchrotron Radiation Laboratory (NSRL, BL01B infrared beamline station, University of Science and Technology of China, China). In addition, dielectric behaviors were surveyed by employing the $\mathrm{TE}_{01 \delta}$ cavity method with a network analyzer (N5234A, Agilent Co., USA) and the Hakki-Coleman dielectric resonator method. The $\tau_{\mathrm{f}}$ value was acquired by Eq. (1):

$$
\tau_{\mathrm{f}}=\frac{f_{\mathrm{T}}-f_{0}}{60 \times f_{0}} \times 10^{6}\left(\mathrm{ppm} /{ }^{\circ} \mathrm{C}\right)
$$

where $f_{\mathrm{T}}$ and $f_{0}$ represent resonant frequencies at 85 and $25{ }^{\circ} \mathrm{C}$, respectively.

Relative density $\left(\rho_{\text {relative }}\right)$ was applied via the following equations:

$$
\begin{aligned}
& \rho_{\text {theory }}=\frac{Z A}{V_{\mathrm{m}} N_{\mathrm{A}}}\left(\mathrm{g} / \mathrm{cm}^{3}\right) \\
& \rho_{\text {relative }}=\frac{\rho_{\text {apparent }}}{\rho_{\text {theory }}} \times 100 \%
\end{aligned}
$$

where $Z$ is the number of molecules, $N_{\mathrm{A}}$ refers to Avogadro constant, $A$ represents the relative atomic weight, and $V_{\mathrm{m}}$ represents the unit cell volume.

\section{Results and discussion}

As shown in Fig. 1, the X-ray diffraction patterns of $\mathrm{Ce}_{2}\left[\mathrm{Zr}_{1-x}\left(\mathrm{Mg}_{1 / 3} \mathrm{Sb}_{2 / 3}\right)_{x}\right]_{3}\left(\mathrm{MoO}_{4}\right)_{9}(0.02 \leqslant x \leqslant 0.10)$ ceramics are sintered under different temperatures for $6 \mathrm{~h}$. A single phase was detected in all samples. The peaks of sintered ceramics assigned to the standard data for $\mathrm{Pr}_{2} \mathrm{Zr}_{3}\left(\mathrm{MoO}_{4}\right)_{9}$ (JCPDS No. 52-0688), which 


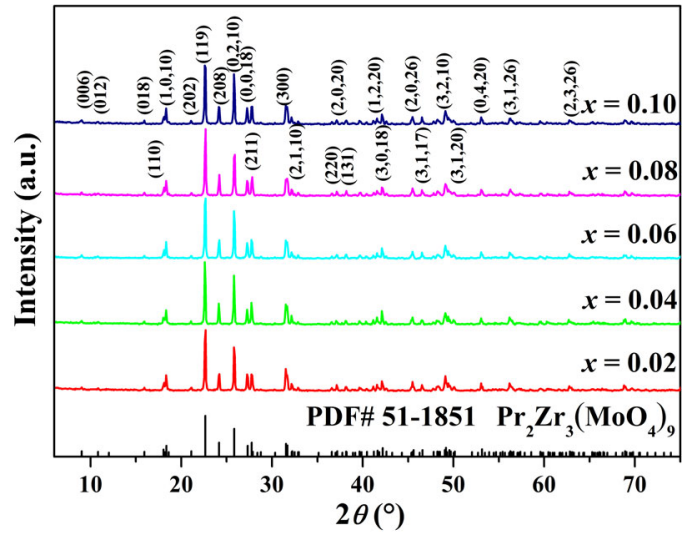

Fig. 1 XRD patterns of $\mathrm{Ce}_{2}\left[\mathrm{Zr}_{1-x}\left(\mathrm{Mg}_{1 / 3} \mathrm{Sb}_{2 / 3}\right)_{x}\right]_{3}\left(\mathrm{MoO}_{4}\right)_{9}$ $(x=0.02,0.04,0.06,0.08$, and 0.10$)$ ceramics sintered at the densification temperature for $6 \mathrm{~h}$.

indicated that the $\mathrm{Pr}_{2} \mathrm{Zr}_{3}\left(\mathrm{MoO}_{4}\right)_{9}$-like crystal structure with a $R \overline{3} c$ space group was obtained. According to the result, the composition of the crystal phase is not changed by the content of $\left(\mathrm{Mg}_{1 / 3} \mathrm{Sb}_{2 / 3}\right)^{4+}$ ions substitution [14]. In order to meet the needs of calculating density and complex chemical bonds, the structure, lattice parameters, bond length, and unit cell volumes were further analyzed and obtained by Rietveld refinement [15]. $\mathrm{Nd}_{2} \mathrm{Zr}_{3}\left(\mathrm{MoO}_{4}\right)_{9}$ was chosen as the original model via FULLPROF program. Refinement plot of $\mathrm{Ce}_{2}\left[\mathrm{Zr}_{1-x}\left(\mathrm{Mg}_{1 / 3} \mathrm{Sb}_{2 / 3}\right)_{x}\right]_{3}\left(\mathrm{MoO}_{4}\right)_{9}(0.02 \leqslant x \leqslant 0.10)$ ceramics are displayed in Fig. 2, in which the observed values are expressed by red points, the calculated values are expressed by the black line, and different values between the observed and the calculated data are expressed by the blue curve. Obviously, excellent agreement is shown between the fitted values and the measured values. In addition, the refined discrepancy factors $\left(R_{\mathrm{wp}}, R_{\mathrm{p}}\right.$, and $\left.\chi^{2}\right), V_{\mathrm{m}}$, and lattice parameters of
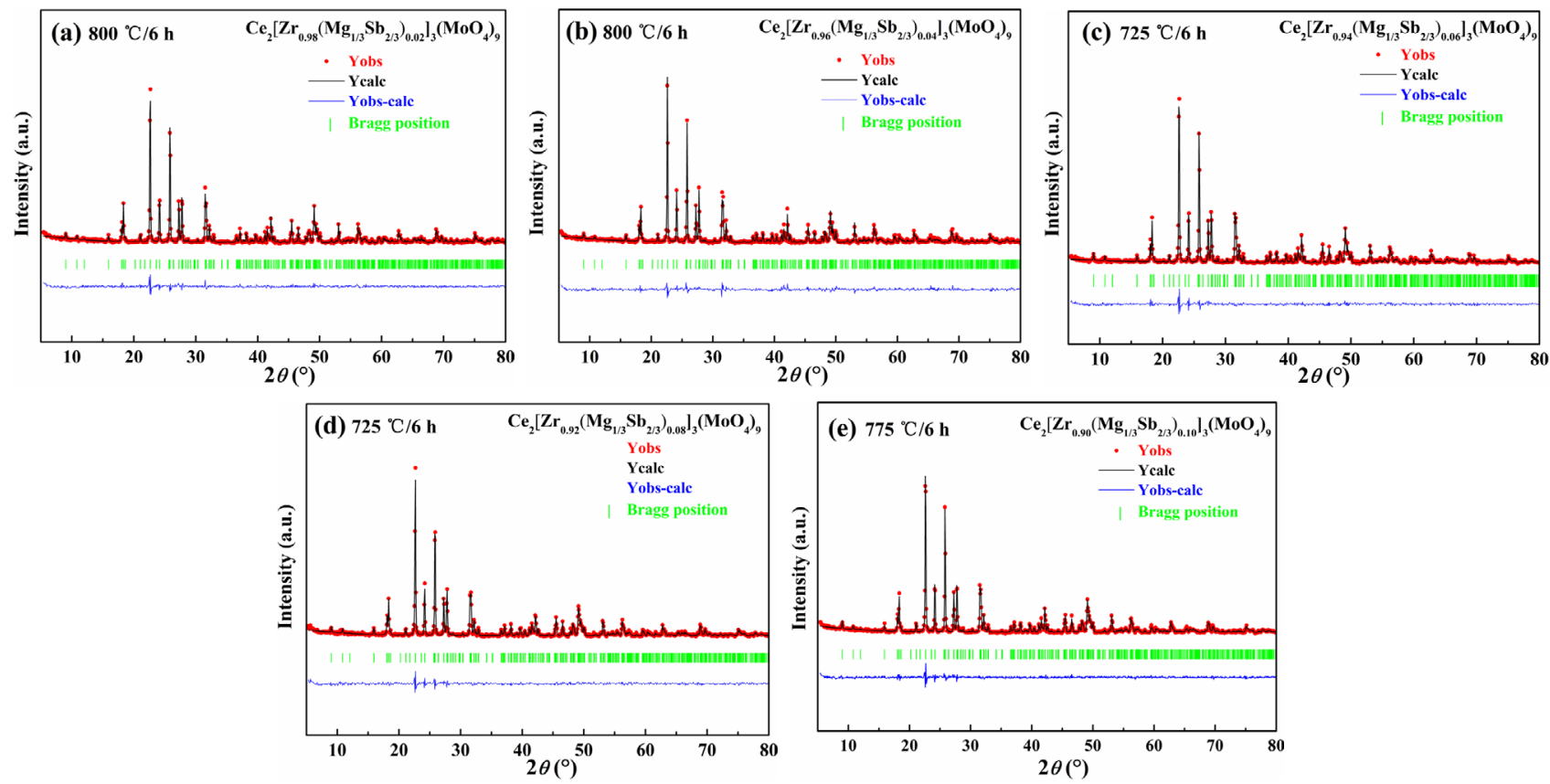

Fig. 2 Refinement results of $\mathrm{Ce}_{2}\left[\mathrm{Zr}_{1-x}\left(\mathrm{Mg}_{1 / 3} \mathrm{Sb}_{2 / 3}\right)_{x}\right]_{3}\left(\mathrm{MoO}_{4}\right)_{9}$ ceramics calcined under various conditions as indicated: (a) $x=$ 0.02 , (b) $x=0.04$, (c) $x=0.06$, (d) $x=0.08$, and (e) $x=0.10$.

Table 2 Refinement parameters of $\mathrm{Ce}_{2}\left[\mathrm{Zr}_{1-x}\left(\mathrm{Mg}_{1 / 3} \mathrm{Sb}_{2 / 3}\right)_{x}\right]_{3}\left(\mathrm{MoO}_{4}\right)_{9}$ ceramics sintered at the optimized sintering temperature

\begin{tabular}{|c|c|c|c|c|c|}
\hline \multirow{2}{*}{ Structural parameter } & \multicolumn{5}{|c|}{$\mathrm{Ce}_{2}\left[\mathrm{Zr}_{1-x}\left(\mathrm{Mg}_{1 / 3} \mathrm{Sb}_{2 / 3}\right)_{x}\right]_{3}\left(\mathrm{MoO}_{4}\right)_{9}$} \\
\hline & $x=0.02$ & $x=0.04$ & $x=0.06$ & $x=0.08$ & $x=0.10$ \\
\hline$a=b(\AA)$ & $9.8344(1)$ & $9.8333(0)$ & $9.8310(9)$ & $9.8288(2)$ & $9.8254(1)$ \\
\hline$c(\AA)$ & $58.8580(5)$ & $58.8603(6)$ & $58.8723(1)$ & $58.8835(0)$ & $58.8729(0)$ \\
\hline$\alpha=\beta\left(^{\circ}\right)$ & 90 & 90 & 90 & 90 & 90 \\
\hline$\gamma\left({ }^{\circ}\right)$ & 120 & 120 & 120 & 120 & 120 \\
\hline$V_{\mathrm{m}}\left(\AA^{3}\right)$ & $4929.84(0)$ & 4928.92(1) & $4928.30(5)$ & $4926.38(1)$ & $4922.07(5)$ \\
\hline$R_{\mathrm{p}}(\%)$ & 8.33 & 8.52 & 6.60 & 7.62 & 7.46 \\
\hline$R_{\mathrm{wp}}(\%)$ & 10.60 & 11.10 & 10.50 & 9.60 & 9.51 \\
\hline$\chi^{2}$ & 2.04 & 2.23 & 1.90 & 1.70 & 1.71 \\
\hline
\end{tabular}

$R_{\mathrm{p}}$ - the reliability factor of patterns; $R_{\mathrm{wp}}$ - the reliability factor of weighted patterns; $\chi^{2}$ - the goodness of fit indicator $=\mathrm{chi}{ }^{2}=\left(R_{\mathrm{wp}} / R_{\mathrm{exp}}\right)^{2}$. 
all specimens are listed in Table 2. The $R_{\mathrm{wp}}, R_{\mathrm{p}}$, and $\chi^{2}$ values were obtained in the range of $9.6 \%-11.1 \%$, $6.6 \%-8.6 \%$, and $1.70-2.23$, respectively, indicating all the refinement results are acceptable and accurate.

With the amount of $\left(\mathrm{Mg}_{1 / 3} \mathrm{Sb}_{2 / 3}\right)^{4+}$ increasing, the linear variation in lattice parameters $(a, b$, and $c)$ and $V_{\mathrm{m}}$ are presented in Fig. 3. The lattice parameter $c$ is linearly increased, but $a, b$, and $V_{\mathrm{m}}$ are linearly decreased correspondingly along with the augment of $\left(\mathrm{Mg}_{1 / 3} \mathrm{Sb}_{2 / 3}\right)^{4+}$ because the ionic radius of $\mathrm{Zr}^{4+}(0.72 \AA)$ is longer than that of $\left(\mathrm{Mg}_{1 / 3} \mathrm{Sb}_{2 / 3}\right)^{4+}(0.64 \AA)[16,17]$. The schematic illustration (Fig. 4) and the refined atomic positions (Table 3) of $\mathrm{Ce}_{2}\left[\mathrm{Zr}_{1-x}\left(\mathrm{Mg}_{1 / 3} \mathrm{Sb}_{2 / 3}\right)_{x}\right]_{3}\left(\mathrm{MoO}_{4}\right)_{9}$ samples are exhibited clearly. The crystal structure of ceramics is composed of $\mathrm{CeO}_{9}, \mathrm{Zr} / \mathrm{Mg} / \mathrm{SbO}_{6}$, and $\mathrm{MoO}_{4}$ polyhedra with common vertex angle.

The apparent densities of $\mathrm{Ce}_{2}\left[\mathrm{Zr}_{1-x}\left(\mathrm{Mg}_{1 / 3} \mathrm{Sb}_{2 / 3}\right)_{x}\right]_{3}\left(\mathrm{MoO}_{4}\right)_{9}$ $(0.02 \leqslant x \leqslant 0.10)$ ceramics as a function of the sintering temperature are illustrated in Fig. 5. As the temperature increases, the apparent densities of each composition increase at first and then decrease slightly. For example, the apparent density of $\mathrm{Ce}_{2}\left[\mathrm{Zr}_{0.94}\left(\mathrm{Mg}_{1 / 3} \mathrm{Sb}_{2 / 3}\right)_{0.06}\right]_{3}\left(\mathrm{MoO}_{4}\right)_{9}$ ceramics increases from 3.71 to $3.83 \mathrm{~g} / \mathrm{cm}^{3}$, and then the

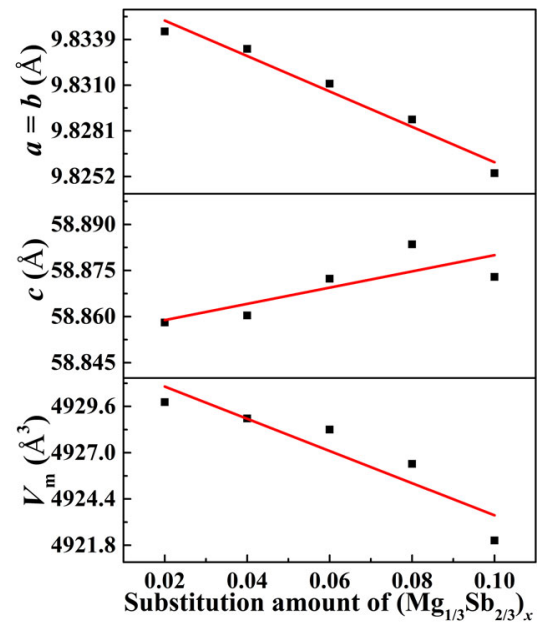

Fig. $3 a, b, c$, and $V_{\mathrm{m}}$ of $\mathrm{Ce}_{2}\left[\mathrm{Zr}_{1-x}\left(\mathrm{Mg}_{1 / 3} \mathrm{Sb}_{2 / 3}\right)_{x}\right]_{3}\left(\mathrm{MoO}_{4}\right)_{9}$ ceramics as a function of the substitution amount of $\left(\mathrm{Mg}_{1 / 3} \mathrm{Sb}_{2 / 3}\right)^{4+}$.

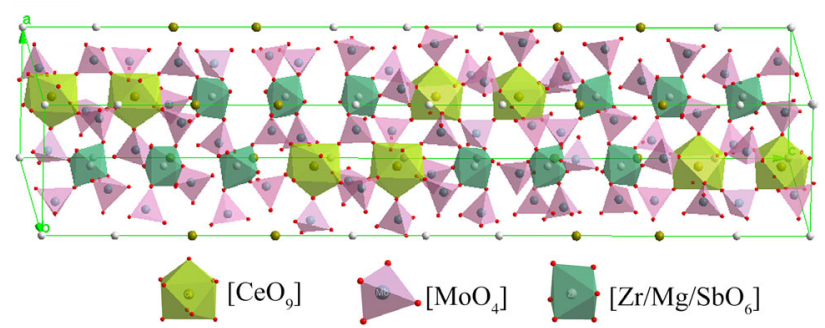

Fig. 4 Schematic illustration of $\mathrm{Ce}_{2}\left[\mathrm{Zr}_{1-x}\left(\mathrm{Mg}_{1 / 3} \mathrm{Sb}_{23}\right)_{x}\right]_{3}\left(\mathrm{MoO}_{4}\right)_{9}$ ceramics. apparent density drops to $3.81 \mathrm{~g} / \mathrm{cm}^{3}$ at $800{ }^{\circ} \mathrm{C}$. In general, an appropriate sintering temperature plays a vital role in the densification of the sample. The higher sintering temperature will accelerate the growth of crystal grains, and the pores will not be discharged in time, resulting in a poor densification sample. The maximum relative density of each composition is embedded in Fig. 5 as a function of $\left(\mathrm{Mg}_{1 / 3} \mathrm{Sb}_{2 / 3}\right)^{4+}$ substitution. The apparent densities of the major sample were approximately $3.80 \mathrm{~g} / \mathrm{cm}^{3}$ and the $\rho_{\text {relative }}$ also has reached more than $95 \%$. It is noticeable that the good degree of densification was in accord with the SEM results. Figures 6(a)-6(e) depict the SEM microphotographs of the specimens at their optimal temperatures. It is quite clear that the dense microstructure and unambiguous grain boundary of the specimens can be observed. As provided in Fig. 6(f), EDS of $\mathrm{Ce}_{2}\left[\mathrm{Zr}_{0.94}\left(\mathrm{Mg}_{1 / 3} \mathrm{Sb}_{2 / 3}\right)_{0.06}\right]_{3}\left(\mathrm{MoO}_{4}\right)_{9}$ ceramics is gained at $725{ }^{\circ} \mathrm{C}$ for $6 \mathrm{~h}$. Atom ratios of O, Mo, $\mathrm{Zr}, \mathrm{Ce}$, $\mathrm{Sb}$, and $\mathrm{Mg}$ are $73.56 \%, 16.91 \%, 5.93 \%, 3.48 \%, 0.07 \%$,

Table 3 Refined atomic positions of $\mathrm{Ce}_{2}\left[\mathrm{Zr}_{1-x}\left(\mathrm{Mg}_{13} \mathrm{Sb}_{23}\right)_{x}\right]_{3}\left(\mathrm{MoO}_{4}\right)_{9}$ samples

\begin{tabular}{ccccccc}
\hline Atom & $\begin{array}{c}\text { Wyckoff } \\
\text { position }\end{array}$ & Site & $x$ & $y$ & $z$ & Occupancy \\
\hline $\mathrm{Ce}$ & $12 \mathrm{c}$ & 3 & 0.6667 & 0.3333 & 0.0297 & 0.3333 \\
$\mathrm{Zr} 1$ & $6 \mathrm{~b}$ & -3 & 0.0000 & 0.0000 & 0.0000 & 0.1667 \\
$\mathrm{Zr} 2$ & $12 \mathrm{c}$ & 3 & 0.3333 & 0.6667 & 0.0712 & 0.3333 \\
$\mathrm{Mo} 1$ & $36 \mathrm{f}$ & 1 & 0.0982 & 0.7275 & 0.0250 & 1.0000 \\
$\mathrm{Mo} 2$ & $18 \mathrm{e}$ & 2 & 0.2834 & 0.2834 & 0.2500 & 0.5000 \\
$\mathrm{O} 1$ & $36 \mathrm{f}$ & 1 & -0.0959 & 0.5941 & 0.0308 & 1.0000 \\
$\mathrm{O} 2$ & $36 \mathrm{f}$ & 1 & 0.1628 & 0.6664 & 0.0027 & 1.0000 \\
$\mathrm{O} 3$ & $36 \mathrm{f}$ & 1 & 0.2061 & 0.7312 & 0.0500 & 1.0000 \\
$\mathrm{O} 4$ & $36 \mathrm{f}$ & 1 & 0.1192 & 0.9207 & 0.0201 & 1.0000 \\
$\mathrm{O} 5$ & $36 \mathrm{f}$ & 1 & 0.2879 & 0.4692 & 0.2456 & 1.0000 \\
$\mathrm{O} 6$ & $36 \mathrm{f}$ & 1 & 0.1708 & 0.1902 & 0.2729 & 1.0000 \\
\hline
\end{tabular}

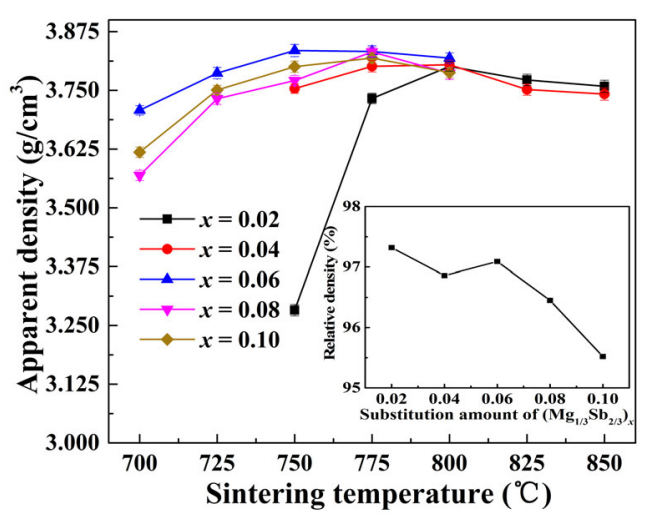

Fig. 5 Apparent densities of $\mathrm{Ce}_{2}\left[\mathrm{Zr}_{1-x}\left(\mathrm{Mg}_{1 / 3} \mathrm{Sb}_{2 / 3}\right)_{x}\right]_{3}\left(\mathrm{MoO}_{4}\right)_{9}$ ceramics as a function of the sintering temperature; the relative densities of each composition are shown in the inset. 

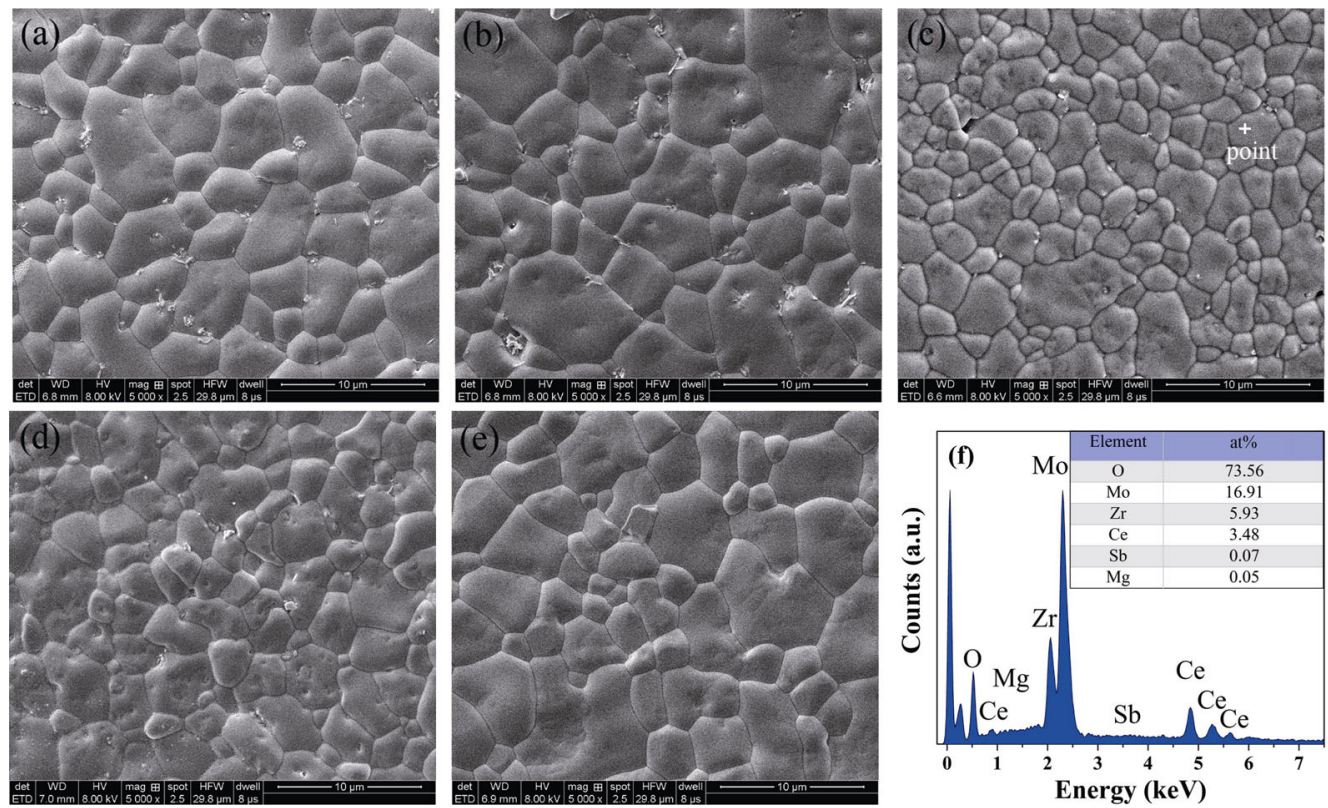

Fig. 6 SEM microphotographs of $\mathrm{Ce}_{2}\left[\mathrm{Zr}_{1-x}\left(\mathrm{Mg}_{1 / 3} \mathrm{Sb}_{2 / 3}\right)_{x}\right]_{3}\left(\mathrm{MoO}_{4}\right)_{9}$ ceramics at the densification temperature for $6 \mathrm{~h}$ : (a) $x=$ 0.02 , (b) $x=0.04$, (c) $x=0.06$, (d) $x=0.08$, and (e) $x=0.10$; (f) EDS analysis of $\mathrm{Ce}_{2}\left[\mathrm{Zr}_{0.94}\left(\mathrm{Mg}_{1 / 3} \mathrm{Sb}_{2 / 3}\right)_{0.06}\right]_{3}\left(\mathrm{MoO}_{4}\right)_{9}$ ceramics sintered at $725{ }^{\circ} \mathrm{C}$ for $6 \mathrm{~h}$; the atom ratios of $\mathrm{Ce}_{2}\left[\mathrm{Zr}_{0.94}\left(\mathrm{Mg}_{1 / 3} \mathrm{Sb}_{2 / 3}\right)_{0.06}\right]_{3}\left(\mathrm{MoO}_{4}\right)_{9}$ ceramic is shown in the inset of Fig. 6(f).

and $0.05 \%$, respectively, which are in consistent with the chemical formula.

The $\varepsilon_{\mathrm{r}}$ of ceramics with different $\left(\mathrm{Mg}_{1 / 3} \mathrm{Sb}_{2 / 3}\right)^{4+}$ contents $(x=0.02,0.04,0.06,0.08$, and 0.10$)$ as a function of the sintering temperature is revealed in Fig. 7(a). The factors that affect the $\varepsilon_{\mathrm{r}}$ are mainly divided into external parameters and intrinsic factors. Intrinsic factors include lattice structure and ionic polarizabilities, whereas external parameters include impurities, density, and second phase [18]. No secondary phase is detected in Fig. 1 and the lattice structure has no change. Thus, the $\varepsilon_{\mathrm{r}}$ of $\mathrm{Ce}_{2}\left[\mathrm{Zr}_{1-x}\left(\mathrm{Mg}_{1 / 3} \mathrm{Sb}_{2 / 3}\right)_{x}\right]_{3}\left(\mathrm{MoO}_{4}\right)_{9}(0.02 \leqslant x \leqslant 0.10)$ ceramics was determined mainly by the apparent density. Figure 5 shows that the apparent densities of the sample increased and then decreased slightly as the temperature increased. It was easy to notice that the $\varepsilon_{\mathrm{r}}$ existed almost similar trend with the apparent density, which indicated that the main contribution of the $\varepsilon_{\mathrm{r}}$ was the apparent density.

The $Q \times f$ of $\mathrm{Ce}_{2}\left[\mathrm{Zr}_{1-x}\left(\mathrm{Mg}_{1 / 3} \mathrm{Sb}_{2 / 3}\right)_{x}\right]_{3}\left(\mathrm{MoO}_{4}\right)_{9}(0.02 \leqslant$ $x \leqslant 0.10$ ) ceramics sintered at $700-850{ }^{\circ} \mathrm{C}$ for $6 \mathrm{~h}$ is plotted in Fig. 7(b). The quality factor depends on the presence of intrinsic and extrinsic dielectric losses at microwave frequencies. The extrinsic losses are dominated by porosity, secondary phase, and lattice defects, whereas the intrinsic loss is mainly contributed by lattice vibrational modes [19]. It was obvious that the $Q \times f$ of each composition existed similar trend, which increased firstly and then decreased. The optimal points of $Q \times f$ were presented at $800,800,725$, 725,725 , and $775{ }^{\circ} \mathrm{C}$, In this study, the excellent
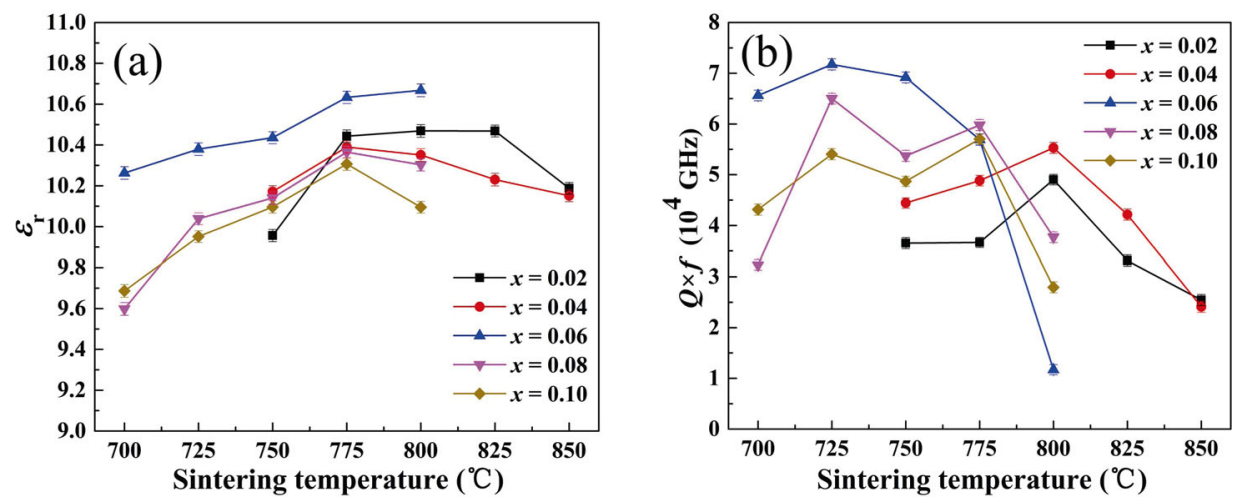

Fig. 7 (a) $\varepsilon_{\mathrm{r}}$ and (b) $Q \times f$ values of $\mathrm{Ce}_{2}\left[\mathrm{Zr}_{1-x}\left(\mathrm{Mg}_{1 / 3} \mathrm{Sb}_{2 / 3}\right)_{x}\right]_{3}\left(\mathrm{MoO}_{4}\right)_{9}$ ceramics sintered at $700-800{ }^{\circ} \mathrm{C}$. 
properties of $\mathrm{Ce}_{2}\left[\mathrm{Zr}_{0.94}\left(\mathrm{Mg}_{1 / 3} \mathrm{Sb}_{2 / 3}\right)_{0.06}\right]_{3}\left(\mathrm{MoO}_{4}\right)_{9}$ ceramics $\left(\varepsilon_{\mathrm{r}}=10.37, Q \times f=71,748 \mathrm{GHz}\right.$, and $\left.\tau_{\mathrm{f}}=-13.6 \mathrm{ppm} /{ }^{\circ} \mathrm{C}\right)$ were obtained at $725{ }^{\circ} \mathrm{C}$ for $6 \mathrm{~h}$. At the optimal sintering temperature, the quality factor of $\mathrm{Ce}_{2}\left[\mathrm{Zr}_{0.94}\left(\mathrm{Mg}_{1 / 3} \mathrm{Sb}_{2 / 3}\right)_{0.06}\right]_{3}\left(\mathrm{MoO}_{4}\right)_{9}$ ceramics has been greatly improved compared to previous reports, owing to the partial replacement of $\mathrm{Zr}^{4+}$ by $\left(\mathrm{Mg}_{1 / 3} \mathrm{Sb}_{2 / 3}\right)^{4+}$ ions.

As we know, chemical bond theory of complex crystals was used to characterize the intrinsic relationships between chemical bond and crystal structure. Wu et al. [15] successfully generalized $\mathrm{P}-\mathrm{V}-\mathrm{L}$ theory, suggesting that the crystalline structure parameters could be calculated by chemical bond. Any complex crystal can be decomposed into multiple binary crystals. The bond equation of $\mathrm{Ce}_{2}\left[\mathrm{Zr}_{1-x}\left(\mathrm{Mg}_{1 / 3} \mathrm{Sb}_{2 / 3}\right)_{x}\right]_{3}\left(\mathrm{MoO}_{4}\right)_{9}(0.02 \leqslant$ $x \leqslant 0.10$ ) ceramics was shown in Eq. (4). In this work, the $\mathrm{Ce}_{2}\left[\mathrm{Zr}_{1-x}\left(\mathrm{Mg}_{1 / 3} \mathrm{Sb}_{2 / 3}\right)_{x}\right]_{3}\left(\mathrm{MoO}_{4}\right)_{9}$ ceramics are constituted of $\mathrm{Ce}-\mathrm{O}, \mathrm{Zr}(\mathrm{Mg} / \mathrm{Sb})-\mathrm{O}$ and $\mathrm{Mo}-\mathrm{O}$ bonds. The effective valences of cations are $P_{\mathrm{Ce}}=3, P_{\mathrm{Zr}(\mathrm{Mg} / \mathrm{Sb})}$ $=4$, and $P_{\mathrm{Mo}}=6$, and the valence of the oxygen ion follows Eq. (4). The effective valences in the $\mathrm{Ce}-\mathrm{O}$ bond, $\mathrm{Zr}(\mathrm{Mg} / \mathrm{Sb})-\mathrm{O}$ bond, and $\mathrm{Mo}-\mathrm{O}$ bond are $P_{\mathrm{O}-\mathrm{Ce}}=$ $-2 / 3, P_{\mathrm{O}-\mathrm{Zr}(\mathrm{Mg} / \mathrm{Sb})}=-4 / 3$, and $P_{\mathrm{O}-\mathrm{Mo}}=-3$, respectively.

$$
\begin{aligned}
\mathrm{Ce}_{2} & {\left[\mathrm{Zr}_{1-x}\left(\mathrm{Mg}_{1 / 3} \mathrm{Sb}_{2 / 3}\right)_{x}\right]_{3}\left(\mathrm{MoO}_{4}\right)_{9} } \\
\rightarrow & \mathrm{Ce}_{2}+\mathrm{Zr} /\left(\mathrm{Mg}_{1 / 3} \mathrm{Sb}_{2 / 3}\right)(1)+\mathrm{Zr} /\left(\mathrm{Mg}_{1 / 3} \mathrm{Sb}_{2 / 3}\right)(2)_{2} \\
& +\mathrm{Mo}(1)_{6}+\mathrm{Mo}(2)_{3}+\mathrm{O}(1)_{6}+\mathrm{O}(2)_{6}+\mathrm{O}(3)_{6} \\
& +\mathrm{O}(4)_{6}+\mathrm{O}(5)_{6}+\mathrm{O}(6)_{6} \\
\rightarrow & \mathrm{Ce}_{2 / 3} \mathrm{O}(1)_{3}+\mathrm{Ce}_{2 / 3} \mathrm{O}(2)_{3}+\mathrm{Ce}_{2 / 3} \mathrm{O}(6)_{3} \\
& +\mathrm{Zr} /\left(\mathrm{Mg}_{1 / 3} \mathrm{Sb}_{2 / 3}\right)(1) \mathrm{O}(4)_{3}+\mathrm{Zr} /\left(\mathrm{Mg}_{1 / 3} \mathrm{Sb}_{2 / 3}\right)(2) \mathrm{O}(3)_{3} \\
& +\mathrm{Zr} /\left(\mathrm{Mg}_{1 / 3} \mathrm{Sb}_{2 / 3}\right)(2) \mathrm{O}(5)_{3}+\mathrm{Mo}(1)_{3 / 2} \mathrm{O}(1)_{3} \\
& +\mathrm{Mo}(1)_{3 / 2} \mathrm{O}(2)_{3}+\mathrm{Mo}(1)_{3 / 2} \mathrm{O}(3)_{3}+\mathrm{Mo}(1)_{3 / 2} \mathrm{O}(4)_{3} \\
& +\mathrm{Mo}(2)_{3 / 2} \mathrm{O}(5)_{3}+\mathrm{Mo}(2)_{3 / 2} \mathrm{O}(6)_{3}
\end{aligned}
$$

The bond ionicity $\left(f_{\mathrm{i}}\right)$ usually could be evaluated by using Eqs. (5)-(9) [15,20,21]:

$$
\begin{gathered}
\varepsilon_{\mathrm{r}}=\frac{n_{0}{ }^{2}-1}{1-f_{\mathrm{i}}}+1 \\
f_{\mathrm{i}}^{\mu}=\frac{\left(C^{\mu}\right)^{2}}{\left(E_{\mathrm{g}}^{\mu}\right)^{2}} \\
\left(E_{\mathrm{g}}^{\mu}\right)^{2}=\left(E_{\mathrm{h}}^{\mu}\right)^{2}+\left(C^{\mu}\right)^{2} \\
\left(E_{\mathrm{h}}^{\mu}\right)^{2}=\frac{39.74}{\left(d^{\mu}\right)^{2.48}} \\
C^{\mu}=14.4 b^{\mu} \exp \left(-k_{\mathrm{s}}^{\mu} r_{0}^{\mu}\right)\left[\left(Z_{\mathrm{A}}^{\mu}\right)^{*}-\frac{n}{m}\left(Z_{\mathrm{B}}^{\mu}\right)^{*}\right] / r_{0}^{\mu}
\end{gathered}
$$

where $d^{\mu}$ and $b^{\mu}$ are the bond length and correction factor, respectively, $\left(Z_{\mathrm{A}}^{\mu}\right)^{*}$ is the effective number of valence electrons on cation $\mathrm{A},\left(Z_{\mathrm{B}}^{\mu}\right)^{*}$ is the effective number of valence electrons on anion $\mathrm{B}, n_{0}$ represents the refractive index, $r_{0}^{\mu}$ is the average radius of $\mathrm{A}$ and $\mathrm{B}$ in angstroms, $m$ and $n$ are obtained from the binary crystal $\mathrm{A}_{m} \mathrm{~B}_{n}$ type compounds, $E_{\mathrm{g}}^{\mu}$ represents the average energy gap, $E_{\mathrm{h}}^{\mu}$ represents the homopolar part, $f_{\mathrm{i}}^{\mu}$ is the bond ionicity of an individual bond $\mu$, $C^{\mu}$ represents the heteropolar part, and $\exp \left(-k_{\mathrm{s}}^{\mu} r_{0}^{\mu}\right)$ is Thomas-Fermi screening factor [22].

The $f_{\mathrm{i}}$ is explored quantitatively as shown in Table 4 . In addition, $\varepsilon_{\mathrm{r}}$ and an individual bond ionicity $f_{\mathrm{i}(\mathrm{Mol}-\mathrm{O}(2))}$ as a function of the content of $\left(\mathrm{Mg}_{1 / 3} \mathrm{Sb}_{2 / 3}\right)^{4+}$ substitution are shown in Fig. 8. The $\varepsilon_{\mathrm{r}}$ values display a decreasing tendency from 10.47 to 10.03 along with the augment of $\left(\mathrm{Mg}_{1 / 3} \mathrm{Sb}_{2 / 3}\right)^{4+}$. The positive correlation between relative permittivity and $f_{\mathrm{i}}$ is described in Eq. (5). As increasing of $\left(\mathrm{Mg}_{1 / 3} \mathrm{Sb}_{2 / 3}\right)^{4+}$ content, $f_{\mathrm{i}(\mathrm{Mol}-\mathrm{O}(2))}$ and $\varepsilon_{\mathrm{r}}$ values show the same tendency, which indicate the $\varepsilon_{\mathrm{r}}$ values are strongly dependent on $f_{\mathrm{i}(\mathrm{Mo1}-\mathrm{O}(2)) \text {. }}$

Lattice energy can be used to predict and explain many physical and chemical properties of ionic crystals, so the larger the lattice energy, the more stable the structure. The lattice energy ( $U$, Table 5$)$ of specimen could be evaluated according to Eqs. (10)-(13) [15,20,21]. Figure 9 presents $U_{(\mathrm{Zr}(\mathrm{Mg} / \mathrm{Sb}) 1-\mathrm{O}(4))}$ values and the quality factor $Q \times f$ as a variation of $\left(\mathrm{Mg}_{1 / 3} \mathrm{Sb}_{2 / 3}\right)^{4+}$ substitution. The $Q \times f$ values increased from 49,033 to $64,012 \mathrm{GHz}$, and then decreased to 48,690 GHz. They all show the same trend of increasing first and then decreasing, indicating that $Q \times f$ is mainly affected by $U_{(\mathrm{Zr}(\mathrm{Mg} / \mathrm{Sb}) 1-\mathrm{O}(4)) \text {. }}$

$$
U_{\text {cal }}=\sum_{\mu} U_{\mathrm{b}}^{\mu}
$$

$$
U_{\mathrm{b}}^{\mu}=U_{\mathrm{bc}}^{\mu}+U_{\mathrm{bi}}^{\mu}
$$

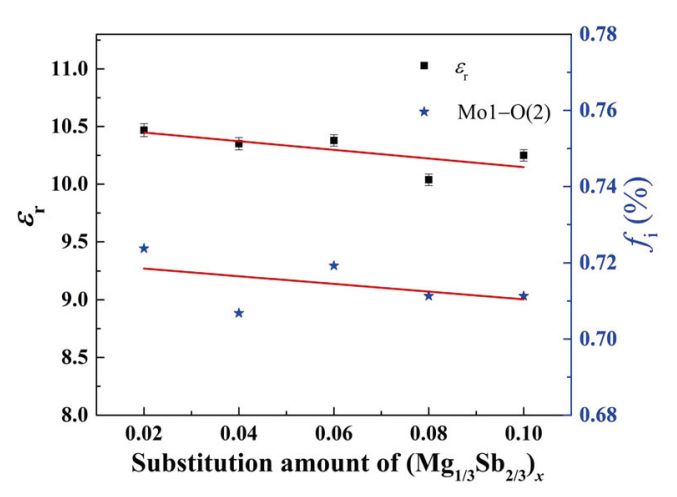

Fig. $8 \quad \varepsilon_{\mathrm{r}}$ and the $\mathrm{Mol}-\mathrm{O}(2)$ bond ionicity of $\mathrm{Ce}_{2}\left[\mathrm{Zr}_{1-x}\left(\mathrm{Mg}_{1 / 3} \mathrm{Sb}_{2 / 3}\right)_{x}\right]_{3}\left(\mathrm{MoO}_{4}\right)_{9}$ ceramics as a function of the content of $\left(\mathrm{Mg}_{1 / 3} \mathrm{Sb}_{2 / 3}\right)^{4+}$ substitution. 
Table $4 f_{\mathrm{i}}$ of $\mathrm{Ce}_{2}\left[\mathrm{Zr}_{1-x}\left(\mathrm{Mg}_{1 / 3} \mathrm{Sb}_{2 / 3}\right)_{x}\right]_{3}\left(\mathrm{MoO}_{4}\right)_{9}(x=0.02-0.10)$ ceramics sintered at the densification temperature for $6 \mathrm{~h}$

\begin{tabular}{|c|c|c|c|c|c|}
\hline \multirow{2}{*}{$\mathrm{Ce}_{2}\left[\mathrm{Zr}_{1-x}\left(\mathrm{Mg}_{1 / 3} \mathrm{Sb}_{2 / 3}\right)_{x}\right]_{3}\left(\mathrm{MoO}_{4}\right)_{9}$} & \multicolumn{5}{|c|}{$f_{\mathrm{i}}(\%)$} \\
\hline & $x=0.02$ & $x=0.04$ & $x=0.06$ & $x=0.08$ & $x=0.10$ \\
\hline $\mathrm{Ce}-\mathrm{O}(1)^{1}$ & 0.8484 & 0.8518 & 0.8467 & 0.8488 & 0.8491 \\
\hline $\mathrm{Ce}-\mathrm{O}(1)^{2}$ & 0.8484 & 0.8518 & 0.8467 & 0.8489 & 0.8491 \\
\hline $\mathrm{Ce}-\mathrm{O}(1)^{3}$ & 0.8485 & 0.8518 & 0.8467 & 0.8489 & 0.8491 \\
\hline $\mathrm{Ce}-\mathrm{O}(2)^{1}$ & 0.8527 & 0.8527 & 0.8553 & 0.8561 & 0.8558 \\
\hline $\mathrm{Ce}-\mathrm{O}(2)^{2}$ & 0.8527 & 0.8527 & 0.8553 & 0.8561 & 0.8558 \\
\hline $\mathrm{Ce}-\mathrm{O}(2)^{3}$ & 0.8527 & 0.8527 & 0.8553 & 0.8561 & 0.8558 \\
\hline $\mathrm{Ce}-\mathrm{O}(6)^{1}$ & 0.8523 & 0.8540 & 0.8524 & 0.8544 & 0.8520 \\
\hline $\mathrm{Ce}-\mathrm{O}(6)^{2}$ & 0.8523 & 0.8540 & 0.8524 & 0.8544 & 0.8521 \\
\hline $\mathrm{Ce}-\mathrm{O}(6)^{3}$ & 0.8523 & 0.8540 & 0.8524 & 0.8545 & 0.8521 \\
\hline $\mathrm{Zr}(\mathrm{Mg} / \mathrm{Sb}) 1-\mathrm{O}(4) \times 6$ & 0.7964 & 0.7868 & 0.7851 & 0.7873 & 0.7880 \\
\hline $\mathrm{Zr}(\mathrm{Mg} / \mathrm{Sb}) 2-\mathrm{O}(3)^{1}$ & 0.7912 & 0.7757 & 0.8014 & 0.7895 & 0.7978 \\
\hline $\mathrm{Zr}(\mathrm{Mg} / \mathrm{Sb}) 2-\mathrm{O}(3)^{2}$ & 0.7912 & 0.7758 & 0.8015 & 0.7895 & 0.7978 \\
\hline $\mathrm{Zr}(\mathrm{Mg} / \mathrm{Sb}) 2-\mathrm{O}(3)^{3}$ & 0.7913 & 0.7758 & 0.8015 & 0.7895 & 0.7979 \\
\hline $\mathrm{Zr}(\mathrm{Mg} / \mathrm{Sb}) 2-\mathrm{O}(5)^{1}$ & 0.7849 & 0.7824 & 0.7920 & 0.7884 & 0.7891 \\
\hline $\mathrm{Zr}(\mathrm{Mg} / \mathrm{Sb}) 2-\mathrm{O}(5)^{2}$ & 0.7850 & 0.7824 & 0.7920 & 0.7884 & 0.7891 \\
\hline $\mathrm{Zr}(\mathrm{Mg} / \mathrm{Sb}) 2-\mathrm{O}(5)^{3}$ & 0.7850 & 0.7825 & 0.7920 & 0.7885 & 0.7892 \\
\hline Mo1-O(1) & 0.7237 & 0.7167 & 0.7298 & 0.7194 & 0.7251 \\
\hline $\mathrm{Mo1}-\mathrm{O}(2)$ & 0.7237 & 0.7068 & 0.7193 & 0.7113 & 0.7113 \\
\hline $\mathrm{Mo1}-\mathrm{O}(3)$ & 0.7315 & 0.7344 & 0.7248 & 0.7348 & 0.7237 \\
\hline $\mathrm{Mo1-O(4)}$ & 0.7369 & 0.7269 & 0.7474 & 0.7377 & 0.7363 \\
\hline Mo2-O(5)×2 & 0.7248 & 0.7344 & 0.7338 & 0.7381 & 0.7288 \\
\hline $\mathrm{Mo} 2-\mathrm{O}(6) \times 2$ & 0.7276 & 0.7064 & 0.7268 & 0.7183 & 0.7258 \\
\hline
\end{tabular}

Superscripts 1,2 , and 3 - three different bonds.

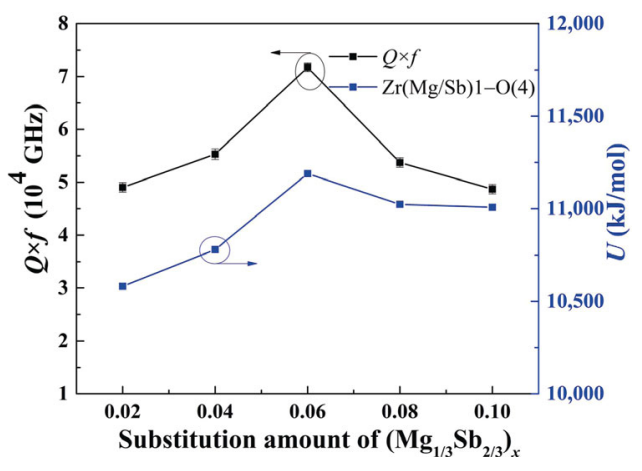

Fig. $9 Q \times f$ and the $\mathrm{Zr}(\mathrm{Mg} / \mathrm{Sb}) 1-\mathrm{O}(4)$ lattice energy of $\mathrm{Ce}_{2}\left[\mathrm{Zr}_{1-x}\left(\mathrm{Mg}_{1 / 3} \mathrm{Sb}_{2 / 3}\right)_{x}\right]_{3}\left(\mathrm{MoO}_{4}\right)_{9}$ ceramics as a function of the content of $\left(\mathrm{Mg}_{1 / 3} \mathrm{Sb}_{2 / 3}\right)^{4+}$ substitution.

$$
\begin{gathered}
U_{\mathrm{bc}}^{\mu}=2100 m \frac{\left(Z_{\mathrm{A}}^{\mu}\right)^{1.64}}{\left(d^{\mu}\right)^{0.75}} f_{\mathrm{C}}^{\mu} \\
U_{\mathrm{bi}}^{\mu}=1270 \frac{(m+n) Z_{\mathrm{A}}^{\mu} Z_{\mathrm{B}}^{\mu}}{d^{\mu}}\left(1-\frac{0.4}{d^{\mu}}\right) f_{\mathrm{i}}^{\mu}
\end{gathered}
$$

where $U_{\mathrm{bi}}^{\mu}$ and $U_{\mathrm{bc}}^{\mu}$ represent ionic energy part and covalent energy part, respectively. $f_{\mathrm{C}}^{\mu}$ is the bond ionicity of an individual bond $\mu . Z_{\mathrm{A}}^{\mu}$ and $Z_{\mathrm{B}}^{\mu}$ are the valence states of cation and anion, respectively, which constituted the $\mu$ bond.

Zhang et al. [23,24] had reported a strong relationship between bond energy $E$ and $\tau_{\mathrm{f}}$, which a smaller $\left|\tau_{\mathrm{f}}\right|$ corresponds to a higher bond energy value. The $E$ value of an individual bond $\mu$ could be calculated by Eqs. (14)-(18) [25-27]:

$$
\begin{gathered}
E^{\mu}=t_{\mathrm{c}} E_{\mathrm{c}}^{\mu}+t_{\mathrm{i}} E_{\mathrm{i}}^{\mu} \\
E_{\mathrm{c}}^{\mu}=\frac{\left(r_{\mathrm{cA}}+r_{\mathrm{cB}}\right)}{d^{\mu}}\left(E_{\mathrm{A}-\mathrm{A}} E_{\mathrm{B}-\mathrm{B}}\right)^{1 / 2}(\mathrm{~kJ} / \mathrm{mol}) \\
E_{\mathrm{i}}^{\mu}=\frac{1389.088}{d^{\mu}}(\mathrm{kJ} / \mathrm{mol}) \\
t_{\mathrm{i}}=\left|\frac{S_{\mathrm{A}}-S_{\mathrm{B}}}{6}\right| \\
t_{\mathrm{c}}+t_{\mathrm{i}}=1
\end{gathered}
$$

where $E^{\mu}$ is bond energy for the type $\mu$ bond, which was composed of nonpolar covalence energy $E_{\mathrm{c}}^{\mu}$ and 
Table $5 U$ of $\mathrm{Ce}_{2}\left[\mathrm{Zr}_{1-x}\left(\mathrm{Mg}_{1 / 3} \mathrm{Sb}_{2 / 3}\right)_{x}\right]_{3}\left(\mathrm{MoO}_{4}\right)_{9}(x=0.02-0.10)$ ceramics sintered at the densification temperature for $6 \mathrm{~h}$

\begin{tabular}{|c|c|c|c|c|c|}
\hline \multirow{2}{*}{$\mathrm{Ce}_{2}\left[\mathrm{Zr}_{1-x}\left(\mathrm{Mg}_{1 / 3} \mathrm{Sb}_{2 / 3}\right)_{x}\right]_{3}\left(\mathrm{MoO}_{4}\right)_{9}$} & \multicolumn{5}{|c|}{$U(\mathrm{~kJ} / \mathrm{mol})$} \\
\hline & $x=0.02$ & $x=0.04$ & $x=0.06$ & $x=0.08$ & $x=0.10$ \\
\hline $\mathrm{Ce}-\mathrm{O}(1)^{1}$ & 3364 & 3208 & 3413 & 3352 & 3354 \\
\hline $\mathrm{Ce}-\mathrm{O}(1)^{2}$ & 3364 & 3207 & 3412 & 3351 & 3352 \\
\hline $\mathrm{Ce}-\mathrm{O}(1)^{3}$ & 3364 & 3207 & 3412 & 3351 & 3352 \\
\hline $\mathrm{Ce}-\mathrm{O}(2)^{1}$ & 3276 & 3188 & 3235 & 3200 & 3212 \\
\hline $\mathrm{Ce}-\mathrm{O}(2)^{2}$ & 3276 & 3188 & 3234 & 3199 & 3212 \\
\hline $\mathrm{Ce}-\mathrm{O}(2)^{3}$ & 3276 & 3188 & 3234 & 3199 & 3211 \\
\hline $\mathrm{Ce}-\mathrm{O}(6)^{1}$ & 3285 & 3160 & 3296 & 3236 & 3291 \\
\hline $\mathrm{Ce}-\mathrm{O}(6)^{2}$ & 3284 & 3160 & 3295 & 3235 & 3291 \\
\hline $\mathrm{Ce}-\mathrm{O}(6)^{3}$ & 3284 & 3159 & 3295 & 3234 & 3291 \\
\hline $\mathrm{Zr}(\mathrm{Mg} / \mathrm{Sb}) 1-\mathrm{O}(4) \times 6$ & 10,580 & 10,780 & 11,189 & 11,023 & 11,007 \\
\hline $\mathrm{Zr}(\mathrm{Mg} / \mathrm{Sb}) 2-\mathrm{O}(3)^{1}$ & 10,844 & 11,319 & 10,360 & 10,916 & 10,512 \\
\hline $\mathrm{Zr}(\mathrm{Mg} / \mathrm{Sb}) 2-\mathrm{O}(3)^{2}$ & 10,842 & 11,317 & 10,358 & 10,914 & 10,510 \\
\hline $\mathrm{Zr}(\mathrm{Mg} / \mathrm{Sb}) 2-\mathrm{O}(3)^{3}$ & 10,842 & 11,315 & 10,358 & 10,913 & 10,509 \\
\hline $\mathrm{Zr}(\mathrm{Mg} / \mathrm{Sb}) 2-\mathrm{O}(5)^{1}$ & 11,152 & 10,998 & 10,850 & 10,968 & 10,955 \\
\hline $\mathrm{Zr}(\mathrm{Mg} / \mathrm{Sb}) 2-\mathrm{O}(5)^{2}$ & 11,151 & 10,997 & 10,849 & 10,967 & 10,954 \\
\hline $\mathrm{Zr}(\mathrm{Mg} / \mathrm{Sb}) 2-\mathrm{O}(5)^{3}$ & 11,149 & 10,995 & 10,847 & 10,965 & 10,951 \\
\hline $\mathrm{Mo1}-\mathrm{O}(1)$ & 43,980 & 43,859 & 43,164 & 44,597 & 43,763 \\
\hline $\mathrm{Mo1-O}(2)$ & 43,964 & 45,433 & 44,862 & 45,862 & 45,940 \\
\hline Mo1-O(3) & 42,658 & 40,742 & 43,989 & 42,023 & 43,995 \\
\hline Mo1-O(4) & 41,707 & 42,121 & 39,969 & 41,489 & 41,852 \\
\hline $\mathrm{Mo} 2-\mathrm{O}(5) \times 2$ & 43,793 & 40,747 & 42,479 & 41,418 & 43,146 \\
\hline Mo2 $-\mathrm{O}(6) \times 2$ & 43,329 & 45,493 & 43,655 & 44,782 & 43,658 \\
\hline
\end{tabular}

complete ionicity energy $E_{\mathrm{i}}^{\mu}$ parts, $S_{\mathrm{A}}$ and $S_{\mathrm{B}}$ represent the electronegativity of ions, $t_{\mathrm{c}}$ and $t_{\mathrm{i}}$ are covalent and ionic blending coefficients, respectively, $r_{\mathrm{cA}}$ and $r_{\mathrm{cB}}$ are the covalent radii, and $E_{\mathrm{A}-\mathrm{A}}$ and $E_{\mathrm{B}-\mathrm{B}}$ are homonuclear bond energy [28].

The $\tau_{\mathrm{f}}$ and an individual bond ionicity $E_{(\mathrm{Mol}-\mathrm{O}(1))}$ as a function of the content of $\left(\mathrm{Mg}_{1 / 3} \mathrm{Sb}_{2 / 3}\right)^{4+}$ substitution are illustrated in Fig. 10. In addition, the calculated $E$

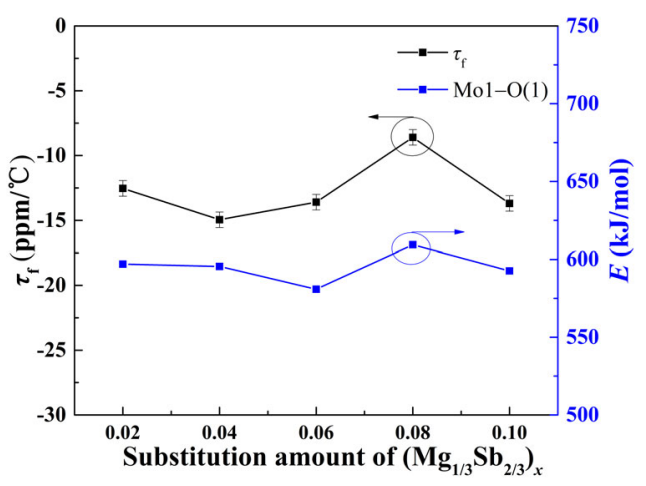

Fig. $10 \quad \tau_{\mathrm{f}}$ and the $\mathrm{Mo1}-\mathrm{O}(1)$ bond energy of $\mathrm{Ce}_{2}\left[\mathrm{Zr}_{1-x}\left(\mathrm{Mg}_{1 / 3} \mathrm{Sb}_{2 / 3}\right)_{x}\right]_{3}\left(\mathrm{MoO}_{4}\right)_{9}$ ceramics as a function of the content of $\left(\mathrm{Mg}_{1 / 3} \mathrm{Sb}_{2 / 3}\right)^{4+}$ substitution. values are shown in Table 6 . The $\tau_{\mathrm{f}}$ values of ceramics fluctuated slightly between -8.59 and $-13.69 \mathrm{ppm} /{ }^{\circ} \mathrm{C}$ with $\left(\mathrm{Mg}_{1 / 3} \mathrm{Sb}_{2 / 3}\right)^{4+}$ increasing in our experiments. The $E_{(\mathrm{Mol}-\mathrm{O}(1))}$ and $\tau_{\mathrm{f}}$ have the same trend, indicating that $\tau_{\mathrm{f}}$ is mainly influenced by $E_{(\mathrm{Mol}-\mathrm{O}(1))}$.

The $\tau_{\mathrm{f}}$ is obtained by Eq. (19) and the $\alpha$ is described via Eqs. (20)-(23):

$$
\begin{gathered}
\tau_{\mathrm{f}}=-\left(\frac{\tau_{\varepsilon}}{2}+\alpha\right) \\
\alpha=\sum_{\mu} F_{m n}^{\mu} \alpha_{m n}^{\mu} \\
\alpha_{m n}^{\mu}=-3.1685+0.8376 \gamma_{m n} \\
\gamma_{m n}=\frac{k Z_{\mathrm{A}}^{\mu} N_{\mathrm{CA}}^{\mu}}{U_{\mathrm{b}}^{\mu} \Delta_{\mathrm{A}}} \beta_{m n} \\
\beta_{m n}=\frac{m(m+n)}{2 n}
\end{gathered}
$$

where $\gamma_{m n}$ is a parameter of the binary bonding formula, $\Delta_{\mathrm{A}}$ is the periodic constant of cation, $k$ is the Boltzmann constant, $N_{\mathrm{CA}}^{\mu}$ represents the coordination 
Table $6 E$ of $\mathrm{Ce}_{2}\left[\mathrm{Zr}_{1-x}\left(\mathrm{Mg}_{1 / 3} \mathrm{Sb}_{2 / 3}\right)_{x}\right]_{3}\left(\mathrm{MoO}_{4}\right)_{9}(x=0.02-0.10)$ ceramics sintered at the densification temperature for $6 \mathrm{~h}$

\begin{tabular}{|c|c|c|c|c|c|}
\hline \multirow{2}{*}{$\mathrm{Ce}_{2}\left[\mathrm{Zr}_{1-x}\left(\mathrm{Mg}_{1 / 3} \mathrm{Sb}_{2 / 3}\right)_{x}\right]_{3}\left(\mathrm{MoO}_{4}\right)_{9}$} & \multicolumn{5}{|c|}{$E(\mathrm{~kJ} / \mathrm{mol})$} \\
\hline & $x=0.02$ & $x=0.04$ & $x=0.06$ & $x=0.08$ & $x=0.10$ \\
\hline $\mathrm{Ce}-\mathrm{O}(1)^{1}$ & 420.9821 & 397.1351 & 428.3333 & 419.0938 & 419.3161 \\
\hline $\mathrm{Ce}-\mathrm{O}(1)^{2}$ & 420.8959 & 397.0431 & 428.2441 & 418.9913 & 419.2306 \\
\hline $\mathrm{Ce}-\mathrm{O}(1)^{3}$ & 420.8097 & 396.9971 & 428.1549 & 418.9230 & 419.1622 \\
\hline $\mathrm{Ce}-\mathrm{O}(2)^{1}$ & 407.8353 & 394.2862 & 401.9027 & 396.5835 & 398.4747 \\
\hline $\mathrm{Ce}-\mathrm{O}(2)^{2}$ & 407.7868 & 394.2408 & 401.8555 & 396.5376 & 398.4283 \\
\hline $\mathrm{Ce}-\mathrm{O}(2)^{3}$ & 407.7382 & 394.1954 & 401.8084 & 396.4917 & 398.3820 \\
\hline $\mathrm{Ce}-\mathrm{O}(6)^{1}$ & 409.1178 & 390.1848 & 410.8842 & 401.8398 & 410.1627 \\
\hline $\mathrm{Ce}-\mathrm{O}(6)^{2}$ & 409.0527 & 390.1552 & 410.8513 & 401.7927 & 410.1136 \\
\hline $\mathrm{Ce}-\mathrm{O}(6)^{3}$ & 409.0038 & 390.0811 & 410.7692 & 401.7299 & 410.0482 \\
\hline $\mathrm{Zr}(\mathrm{Mg} / \mathrm{Sb}) 1-\mathrm{O}(4) \times 6$ & 483.6989 & 494.9655 & 519.9098 & 509.8280 & 508.8463 \\
\hline $\mathrm{Zr}(\mathrm{Mg} / \mathrm{Sb}) 2-\mathrm{O}(3)^{1}$ & 499.2091 & 527.2509 & 470.9886 & 503.4523 & 479.7139 \\
\hline $\mathrm{Zr}(\mathrm{Mg} / \mathrm{Sb}) 2-\mathrm{O}(3)^{2}$ & 499.0641 & 527.0891 & 470.8595 & 503.3048 & 479.5799 \\
\hline $\mathrm{Zr}(\mathrm{Mg} / \mathrm{Sb}) 2-\mathrm{O}(3)^{3}$ & 499.0158 & 527.0352 & 470.8380 & 503.2557 & 479.5353 \\
\hline $\mathrm{Zr}(\mathrm{Mg} / \mathrm{Sb}) 2-\mathrm{O}(5)^{1}$ & 517.6120 & 507.9184 & 499.6205 & 506.5205 & 505.7748 \\
\hline $\mathrm{Zr}(\mathrm{Mg} / \mathrm{Sb}) 2-\mathrm{O}(5)^{2}$ & 517.5340 & 507.8684 & 499.5479 & 506.4707 & 505.7003 \\
\hline $\mathrm{Zr}(\mathrm{Mg} / \mathrm{Sb}) 2-\mathrm{O}(5)^{3}$ & 517.3781 & 507.7182 & 499.4268 & 506.3214 & 505.5515 \\
\hline Mo1-O(1) & 597.0129 & 595.5327 & 580.8629 & 609.3766 & 592.6962 \\
\hline $\mathrm{Mo1}-\mathrm{O}(2)$ & 596.7025 & 627.2896 & 614.5251 & 635.2764 & 636.8040 \\
\hline $\mathrm{Mo1}-\mathrm{O}(3)$ & 571.2568 & 536.2299 & 597.0474 & 559.2248 & 597.2891 \\
\hline $\mathrm{Mo1}-\mathrm{O}(4)$ & 553.2635 & 561.9021 & 521.2639 & 549.2328 & 555.9438 \\
\hline $\mathrm{Mo} 2-\mathrm{O}(5) \times 2$ & 593.3090 & 536.3134 & 567.7086 & 547.9217 & 580.6343 \\
\hline $\mathrm{Mo} 2-\mathrm{O}(6) \times 2$ & 584.2142 & 628.5494 & 590.4598 & 613.1024 & 590.6287 \\
\hline
\end{tabular}

number of cations, $\tau_{\varepsilon}$ is the temperature coefficient of the $\varepsilon_{\mathrm{r}}$, and $F_{m n}^{\mu}$ represents the proportion of $\mu$ bond. Calculated thermal expansion coefficient $\alpha$ values are shown in Table 7. Obviously, the values of $\alpha_{\mathrm{Zr}(\mathrm{Mg} / \mathrm{Sb})-\mathrm{O}}$ and $\alpha_{\mathrm{Ce}-\mathrm{O}}$ are positive. The values of $\alpha_{\mathrm{Mo}-\mathrm{O}}$ have a positive influence on $\tau_{\mathrm{f}}$ because of $\alpha_{\mathrm{Mo}-\mathrm{O}}<0$.

As is known, it is difficult to detect the intrinsic loss and extrinsic loss of microwave dielectric ceramics by conventional testing methods. Far-infrared spectral analysis can reflect the intrinsic loss to a certain extent. These spectra were analyzed by using the classical harmonic oscillator model that was applied to study infrared spectroscopy. It relies on two equations: The standard Lorentzian formula (Eq. (24)) and the Fresnel formula (Eq. (25)) [29,30]. The dielectric loss tangent $\tan \delta$ is evaluated by Eq. (26).

$$
\begin{gathered}
\varepsilon^{*}(\omega)=\varepsilon_{\infty}+\sum_{j=1}^{n} \frac{\omega_{\mathrm{p} j}^{2}}{\omega_{\mathrm{o} j}^{2}-\omega^{2}+j \omega \gamma_{j}} \\
R=\left|\frac{1-\sqrt{\varepsilon^{*}(\omega)}}{\mid 1+\sqrt{\varepsilon^{*}(\omega)}}\right|^{2}
\end{gathered}
$$

$$
\tan \delta=\frac{\varepsilon^{\prime \prime}}{\varepsilon^{\prime}}=\frac{\sum_{j=1}^{n} \Delta \varepsilon_{j}\left(\gamma_{j} \omega\right) / \omega_{\mathrm{oj}}^{2}}{\varepsilon_{\infty}+\sum_{j=1}^{n} \Delta \varepsilon_{j}}
$$

where $\Delta \varepsilon_{j}$ is contribution from each mode, $\gamma_{j}$ is the damping factor, $\omega$ is frequency, $\varepsilon^{\prime}$ and $\varepsilon^{\prime \prime}$ are the real part and imaginary parts of the permittivity, respectively, $\varepsilon_{\infty}$ is the relative permittivity caused by electronic polarization, $\omega_{\mathrm{p} j}$ is the plasma frequency, $\varepsilon^{*}(\omega)$ is the complex dielectric function, $\omega_{0 j}$ is the transverse frequency, $n$ is the number of transverse phonon modes, and $R$ is the infrared reflectivity.

As shown in Fig. 11(a), the fitted infrared spectrum of the $\mathrm{Ce}_{2}\left[\mathrm{Zr}_{0.94}\left(\mathrm{Mg}_{1 / 3} \mathrm{Sb}_{2 / 3}\right)_{0.06}\right]_{3}\left(\mathrm{MoO}_{4}\right)_{9}$ sample is depicted. The fitted infrared reflectivity spectrum is in good agreement with the measured part. In addition, real and imaginary parts of the permittivity are given in Fig. 11(b). Table 8 lists the fitted phonon parameters, indicating they are fitted with 16 modes. As compared with the measured permittivity, the calculated one was slightly large. The measured value $\left(1.35 \times 10^{-4}\right)$ and 
Table $7 \alpha$ of $\mathrm{Ce}_{2}\left[\mathrm{Zr}_{1-x}\left(\mathrm{Mg}_{1 / 3} \mathrm{Sb}_{2 / 3}\right)_{x}\right]_{3}\left(\mathrm{MoO}_{4}\right)_{9}(x=0.02-0.10)$ ceramics sintered at the densification temperature for $6 \mathrm{~h}$

\begin{tabular}{|c|c|c|c|c|c|}
\hline \multirow{2}{*}{$\mathrm{Ce}_{2}\left[\mathrm{Zr}_{1-x}\left(\mathrm{Mg}_{1 / 3} \mathrm{Sb}_{2 / 3}\right)_{x}\right]_{3}\left(\mathrm{MoO}_{4}\right)_{9}$} & \multicolumn{5}{|c|}{$\alpha\left(10^{-6} / \mathrm{K}\right)$} \\
\hline & $x=0.02$ & $x=0.04$ & $x=0.06$ & $x=0.08$ & $x=0.10$ \\
\hline $\mathrm{Ce}-\mathrm{O}(1)^{1}$ & 9.9082 & 10.5441 & 9.7205 & 9.9551 & 9.9472 \\
\hline $\mathrm{Ce}-\mathrm{O}(1)^{2}$ & 9.9082 & 10.5484 & 9.7243 & 9.9590 & 9.9551 \\
\hline $\mathrm{Ce}-\mathrm{O}(1)^{3}$ & 9.9082 & 10.5484 & 9.7243 & 9.9590 & 9.9551 \\
\hline $\mathrm{Ce}-\mathrm{O}(2)^{1}$ & 10.2595 & 10.6302 & 10.4297 & 10.5784 & 10.5271 \\
\hline $\mathrm{Ce}-\mathrm{O}(2)^{2}$ & 10.2595 & 10.6302 & 10.4339 & 10.5827 & 10.5271 \\
\hline $\mathrm{Ce}-\mathrm{O}(2)^{3}$ & 10.2595 & 10.6302 & 10.4339 & 10.5827 & 10.5313 \\
\hline $\mathrm{Ce}-\mathrm{O}(6)^{1}$ & 10.2227 & 10.7524 & 10.1780 & 10.4255 & 10.1983 \\
\hline $\mathrm{Ce}-\mathrm{O}(6)^{2}$ & 10.2268 & 10.7524 & 10.1821 & 10.4297 & 10.1983 \\
\hline $\mathrm{Ce}-\mathrm{O}(6)^{3}$ & 10.2268 & 10.7568 & 10.1821 & 10.4339 & 10.1983 \\
\hline $\mathrm{Zr}(\mathrm{Mg} / \mathrm{Sb}) 1-\mathrm{O}(4) \times 6$ & 3.5771 & 3.4520 & 3.2100 & 3.3060 & 3.3154 \\
\hline $\mathrm{Zr}(\mathrm{Mg} / \mathrm{Sb}) 2-\mathrm{O}(3)^{1}$ & 3.4129 & 3.1367 & 3.7204 & 3.3695 & 3.6208 \\
\hline $\mathrm{Zr}(\mathrm{Mg} / \mathrm{Sb}) 2-\mathrm{O}(3)^{2}$ & 3.4141 & 3.1378 & 3.7217 & 3.3707 & 3.6220 \\
\hline $\mathrm{Zr}(\mathrm{Mg} / \mathrm{Sb}) 2-\mathrm{O}(3)^{3}$ & 3.4141 & 3.1389 & 3.7217 & 3.3713 & 3.6227 \\
\hline $\mathrm{Zr}(\mathrm{Mg} / \mathrm{Sb}) 2-\mathrm{O}(5)^{1}$ & 3.2311 & 3.3207 & 3.4093 & 3.3385 & 3.3462 \\
\hline $\mathrm{Zr}(\mathrm{Mg} / \mathrm{Sb}) 2-\mathrm{O}(5)^{2}$ & 3.2317 & 3.3213 & 3.4099 & 3.3391 & 3.3468 \\
\hline $\mathrm{Zr}(\mathrm{Mg} / \mathrm{Sb}) 2-\mathrm{O}(5)^{3}$ & 3.2329 & 3.3225 & 3.4111 & 3.3403 & 3.3486 \\
\hline Mo1-O(1) & -0.4301 & -0.4225 & -0.3783 & -0.4680 & -0.4165 \\
\hline $\mathrm{Mo1-O}(2)$ & -0.4291 & -0.5177 & -0.4839 & -0.5425 & -0.5469 \\
\hline Mo1-O(3) & -0.3452 & -0.2125 & -0.4307 & -0.3026 & -0.4310 \\
\hline Mo1-O(4) & -0.2809 & -0.3092 & -0.1553 & -0.2657 & -0.2909 \\
\hline Mo2 $-\mathrm{O}(5) \times 2$ & -0.4184 & -0.2128 & -0.3333 & -0.2607 & -0.3772 \\
\hline Mo2 $-\mathrm{O}(6) \times 2$ & -0.3890 & -0.5212 & -0.4097 & -0.4791 & -0.4099 \\
\hline
\end{tabular}
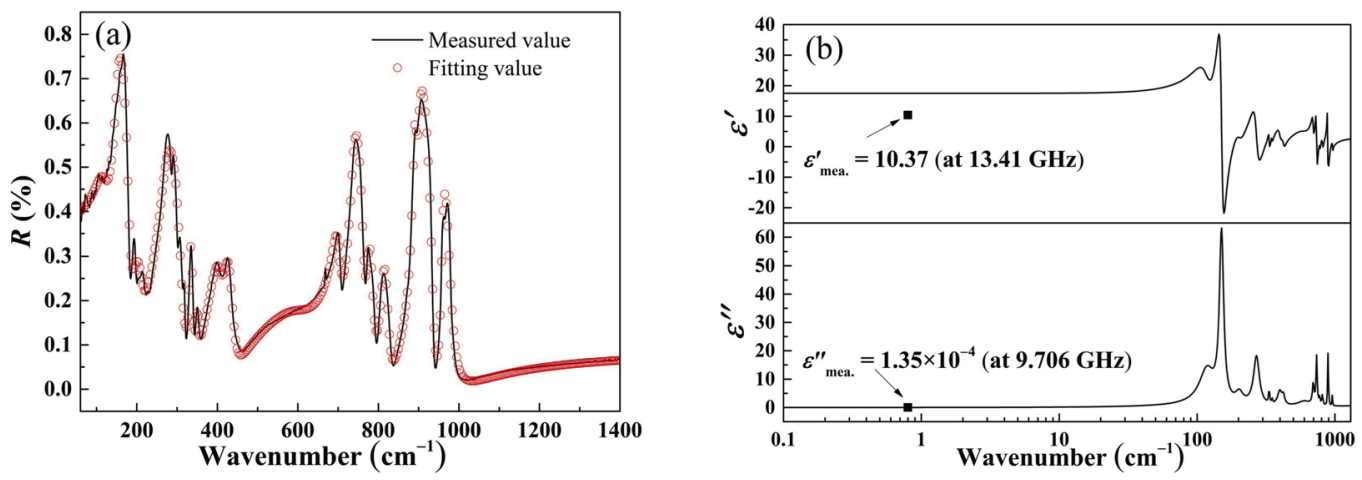

Fig. 11 (a) Measured (black line) and fitted (red line) infrared reflectivity spectra and (b) real and imaginary parts of the complex permittivity for $\mathrm{Ce}_{2}\left[\mathrm{Zr}_{0.94}\left(\mathrm{Mg}_{1 / 3} \mathrm{Sb}_{2 / 3}\right)_{0.06}\right]_{3}\left(\mathrm{MoO}_{4}\right)_{9}$ ceramic sintered at $725{ }^{\circ} \mathrm{C}$ for $6 \mathrm{~h}$.

Table 8 Phonon parameters after fitting of the $\mathrm{Ce}_{2}\left[\mathrm{Zr}_{0.94}\left(\mathrm{Mg}_{1 / 3} \mathrm{Sb}_{2 / 3}\right)_{0.06}\right]_{3}\left(\mathrm{MoO}_{4}\right)_{9}$ sample sintered at $725{ }^{\circ} \mathrm{C}$ for $6 \mathrm{~h}$

\begin{tabular}{|c|c|c|c|c|c|c|c|c|c|}
\hline \multirow{2}{*}{ Mode } & \multicolumn{3}{|c|}{$\mathrm{Ce}_{2}\left[\mathrm{Zr}_{0.94}\left(\mathrm{Mg}_{1 / 3} \mathrm{Sb}_{2 / 3}\right)_{0.06}\right]_{3}\left(\mathrm{MoO}_{4}\right)_{9}$} & $\varepsilon_{\infty}=2.85$ & \multirow{2}{*}{ Mode } & \multicolumn{4}{|c|}{$\mathrm{Ce}_{2}\left[\mathrm{Zr}_{0.94}\left(\mathrm{Mg}_{1 / 3} \mathrm{Sb}_{2 / 3}\right)_{0.06}\right]_{3}\left(\mathrm{MoO}_{4}\right)_{9} \quad \varepsilon_{\infty}=2.85$} \\
\hline & $\omega_{\mathrm{o} j}$ & $\omega_{\mathrm{p} j}$ & $\gamma_{j}$ & $\Delta \varepsilon_{j}$ & & $\omega_{\mathrm{o} j}$ & $\omega_{\mathrm{p} j}$ & $\gamma_{j}$ & $\Delta \varepsilon_{j}$ \\
\hline 1 & 118.72 & 225.22 & 35.46 & 3.60 & 9 & 602.91 & 412.83 & 155.98 & 0.47 \\
\hline 2 & 150.75 & 341.96 & 12.89 & 5.15 & 10 & 695.94 & 338.65 & 22.47 & 0.24 \\
\hline 3 & 202.86 & 162.23 & 31.95 & 0.64 & 11 & 736.26 & 462.78 & 17.08 & 0.40 \\
\hline 4 & 270.42 & 386.82 & 31.62 & 2.05 & 12 & 774.75 & 178.17 & 15.75 & 0.05 \\
\hline 5 & 333.43 & 104.55 & 6.68 & 0.10 & 13 & 811.10 & 228.68 & 18.10 & 0.08 \\
\hline 6 & 350.41 & 60.52 & 5.92 & 0.03 & 14 & 888.05 & 388.88 & 7.79 & 0.19 \\
\hline 7 & 398.23 & 259.20 & 34.10 & 0.42 & 15 & 898.43 & 238.71 & 12.23 & 0.07 \\
\hline 8 & 422.68 & 169.58 & 22.11 & 0.16 & 16 & 957.54 & 192.66 & 9.89 & 0.04 \\
\hline
\end{tabular}


calculated value $\left(2.68 \times 10^{-4}\right)$ of the dielectric loss remained in the same order of magnitude. Both the fitted and measured values correspond well, which indicate that in the microwave frequencies, the dielectric polarization is mainly caused by absorption of phonons in the infrared region [31-33].

\section{Conclusions}

$\mathrm{Ce}_{2}\left[\mathrm{Zr}_{1-x}\left(\mathrm{Mg}_{1 / 3} \mathrm{Sb}_{2 / 3}\right)_{x}\right]_{3}\left(\mathrm{MoO}_{4}\right)_{9}(x=0.02,0.04,0.06$, 0.08 , and 0.10$)$ ceramics were fabricated well via the traditional solid-state method. The pure-phase with space group of $R \overline{3} c$ was detected for all specimens. The dense microstructure and clear grain boundary of specimens can be observed in SEM photos. The crystal structures were investigated deeply by the Rietveld refinement method. The $\varepsilon_{\mathrm{r}}, Q \times f$, and $\tau_{\mathrm{f}}$ values of these samples were strongly dependent on chemical bonds such as $f_{\mathrm{i}(\mathrm{Mol}-\mathrm{O}(2))}, U_{(\mathrm{Zr}(\mathrm{Mg} / \mathrm{Sb}) 1-\mathrm{O}(4))}$, and $E_{(\mathrm{Mol}-\mathrm{O}(1))}$, respectively. The infrared reflectivity spectra were in good agreement with the dielectric properties of samples. Meanwhile, $\mathrm{Ce}_{2}\left[\mathrm{Zr}_{0.94}\left(\mathrm{Mg}_{1 / 3} \mathrm{Sb}_{2 / 3}\right)_{0.06}\right]_{3}\left(\mathrm{MoO}_{4}\right)_{9}$ ceramic with $\varepsilon_{\mathrm{r}}=10.37, Q \times f=71,748 \mathrm{GHz}$, and $\tau_{\mathrm{f}}=-13.6 \mathrm{ppm} /{ }^{\circ} \mathrm{C}$ was obtained at $725^{\circ} \mathrm{C}$ for $6 \mathrm{~h}$.

\section{Acknowledgements}

This work was supported by the National Natural Science Foundation (No. 51972143). The authors would like to thank the administrators in infrared beamline workstation of National Synchrotron Radiation Laboratory (NSRL) for the help in infrared measurement.

\section{References}

[1] Guo HH, Zhou D, Liu WF, et al. Microwave dielectric properties of temperature-stable zircon-type $(\mathrm{Bi}, \mathrm{Ce}) \mathrm{VO}_{4}$ solid solution ceramics. J Am Ceram Soc 2020, 103: 423-431.

[2] Zheng JJ, Yang YK, Wu HT, et al. Structure, infrared spectra and microwave dielectric properties of the novel $\mathrm{Eu}_{2} \mathrm{TiO}_{5}$ ceramics. $J$ Am Ceram Soc 2020, 103: 4333-4341.

[3] Li CC, Yin CZ, Deng M, et al. Tunable microwave dielectric properties in $\mathrm{SrO}-\mathrm{V}_{2} \mathrm{O}_{5}$ system through compositional modulation. J Am Ceram Soc 2020, 103: 2315-2321.

[4] Bi JX, Xing CF, Yang CH, et al. Phase composition, microstructure and microwave dielectric properties of rock salt structured $\mathrm{Li}_{2} \mathrm{ZrO}_{3}-\mathrm{MgO}$ ceramics. J Eur Ceram Soc
2018, 38: 3840-3846.

[5] Pang LX, Zhou D. Modification of $\mathrm{NdNbO}_{4}$ microwave dielectric ceramic by Bi substitutions. J Am Ceram Soc 2019, 102: 2278-2282.

[6] Yin CZ, Li CC, Yang GJ, et al. $\mathrm{NaCa}_{4} \mathrm{~V}_{5} \mathrm{O}_{17}$ : A low-firing microwave dielectric ceramic with low permittivity and chemical compatibility with silver for LTCC applications. $J$ Eur Ceram Soc 2020, 40: 386-390.

[7] Tao BJ, Wang WF, Liu HY, et al. Low-temperature sintering LiF-doped $\quad \mathrm{Li}_{4} \mathrm{Mg}_{3}\left[\mathrm{Ti}_{0.6}\left(\mathrm{Mg}_{1 / 3} \mathrm{Nb}_{2 / 3}\right)_{0.4}\right]_{2} \mathrm{O}_{9}$ microwave dielectric ceramics for LTCC applications. Ceram Int 2021, 47: 2584-2590.

[8] Guo HH, Zhou D, Pang LX, et al. Microwave dielectric properties of low firing temperature stable scheelite structured $(\mathrm{Ca}, \mathrm{Bi})(\mathrm{Mo}, \mathrm{V}) \mathrm{O}_{4}$ solid solution ceramics for LTCC applications. J Eur Ceram Soc 2019, 39: 2365-2373.

[9] Liu WQ, Zuo RZ. Low temperature fired $\mathrm{Ln}_{2} \mathrm{Zr}_{3}\left(\mathrm{MoO}_{4}\right)_{9}$ $(\mathrm{Ln}=\mathrm{Sm}, \mathrm{Nd})$ microwave dielectric ceramics. Ceram Int 2017, 43: 17229-17232.

[10] Zhang YH, Sun JJ, Dai N, et al. Crystal structure, infrared spectra and microwave dielectric properties of novel extra low-temperature fired $\mathrm{Eu}_{2} \mathrm{Zr}_{3}\left(\mathrm{MoO}_{4}\right)_{9}$ ceramics. $J$ Eur Ceram Soc 2019, 39: 1127-1131.

[11] Zhang YH, Wu HT. Crystal structure and microwave dielectric properties of $\mathrm{La}_{2}\left(\mathrm{Zr}_{1-x} \mathrm{Ti}_{x}\right)_{3}\left(\mathrm{MoO}_{4}\right)_{9}(0 \leq x \leq 0.1)$ ceramics. J Am Ceram Soc 2019, 102: 4092-4102.

[12] Tao BJ, Xing CF, Wang WF, et al. A novel $\mathrm{Ce}_{2} \mathrm{Zr}_{3}\left(\mathrm{MoO}_{4}\right)_{9}$ microwave dielectric ceramic with ultra-low firing temperature. Ceram Int 2019, 45: 24675-24683.

[13] Zheng JJ, Liu YH, Tao BJ, et al. Crystal structure and optimised microwave dielectric properties of $\mathrm{Ce}_{2}\left(\mathrm{Zr}_{1-x} \mathrm{Ti}_{x}\right)_{3}\left(\mathrm{MoO}_{4}\right)_{9}$ solid solutions. Ceram Int 2021, 47: 5624-5630.

[14] Xiao M, He SS, Meng J, et al. Bond ionicity, lattice energy, bond energy and the microwave dielectric properties of non-stoichiometric $\mathrm{MgZrNb}_{2+x} \mathrm{O}_{8+2.5 x}$ ceramics. Mater Chem Phys 2020, 242: 122412.

[15] Wu ZJ, Meng QB, Zhang SY. Semiempirical study on the valences of $\mathrm{Cu}$ and bond covalency in $\mathrm{Y}_{1-x} \mathrm{Ca}_{x} \mathrm{Ba}_{2} \mathrm{Cu}_{3} \mathrm{O}_{6-y}$. Phys Rev B 1998, 58: 958-962.

[16] Kim SH, Kim ES. Intrinsic factors affecting the microwave dielectric properties of $\mathrm{Mg}_{2} \mathrm{Ti}_{1-x}\left(\mathrm{Mg}_{1 / 3} \mathrm{Sb}_{2 / 3}\right)_{x} \mathrm{O}_{4}$ ceramics. Ceram Int 2016, 42: 15035-15040.

[17] Pei CJ, Tan JJ, Li Y, et al. Effect of Sb-site nonstoichiometry on the structure and microwave dielectric properties of $\mathrm{Li}_{3} \mathrm{Mg}_{2} \mathrm{Sb}_{1-x} \mathrm{O}_{6}$ ceramics. J Adv Ceram 2020, 9: 588-594.

[18] Xia WS, Zhang LY, Wang Y, et al. Extrinsic effects on microwave dielectric properties of high-Q $\mathrm{MgZrTa}_{2} \mathrm{O}_{8}$ ceramics. J Mater Sci: Mater Electron 2016, 27: 11325 11330.

[19] Silverman BD. Microwave absorption in cubic strontium titanate. Phys Rev 1962, 125: 1921-1930.

[20] Xue DF, Zhang SY. Calculation of the nonlinear optical coefficient of the $\mathrm{NdAl}_{3}\left(\mathrm{BO}_{3}\right)_{4}$ crystal. $J$ Phys: Condens 
Matter 1996, 8: 1949-1956.

[21] Berkov DV. Evaluation of the energy barrier distribution in many-particle systems using the path integral approach. $J$ Phys: Condens Matter 1998, 10: L89-L95.

[22] Levine BF. Bond susceptibilities and ionicities in complex crystal structures. J Chem Phys 1973, 59: 1463-1486.

[23] Zhang P, Zhao YG, Wang XY. The correlations between electronic polarizability, packing fraction, bond energy and microwave dielectric properties of $\mathrm{Nd}\left(\mathrm{Nb}_{1-x} \mathrm{Sb}_{x}\right) \mathrm{O}_{4}$ ceramics. J Alloys Compd 2015, 644: 621-625.

[24] Zhang P, Zhao YG. Effects of structural characteristics on microwave dielectric properties of $\mathrm{Li}_{2} \mathrm{Mg}\left(\mathrm{Ti}_{1-x} \mathrm{Mn}_{x}\right)_{3} \mathrm{O}_{8}$ ceramics. J Alloys Compd 2015, 647: 386-391.

[25] Sanderson RT. Multiple and single bond energies in inorganic molecules. J Inorg Nucl Chem 1968, 30: 375393.

[26] Sanderson RT. Chemical Bonds, Bond Energy. New York (USA): Academic press, 1971.

[27] Sanderson RT. Electronegativity and bond energy. J Am Chem Soc 1983, 105: 2259-2261.

[28] Luo YR. Comprehensive Handbook of Chemical Bond Energies. Boca Raton (USA): CRC press, 2007.

[29] Chen Z, Jia H, Sharafudeen K, et al. Up-conversion luminescence from single vanadate through blackbody radiation harvesting broadband near-infrared photons for photovoltaic cells. J Alloys Compd 2016, 663: 204-210.

[30] Guo J, Zhou D, Wang L, et al. Infrared spectra, Raman spectra, microwave dielectric properties and simulation for effective permittivity of temperature stable ceramics $\mathrm{AMoO}_{4}-\mathrm{TiO}_{2}(\mathrm{~A}=\mathrm{Ca}, \mathrm{Sr})$. Dalton Trans 2013, 42: 1483-1491.

[31] Pang LX, Zhou D, Qi ZM, et al. Structure-property relationships of low sintering temperature scheelitestructured $(1-x) \mathrm{BiVO}_{4}-x \mathrm{LaNbO}_{4}$ microwave dielectric ceramics. J Mater Chem C 2017, 5: 2695-2701.

[32] Liu LT, Chen YG, Feng ZB, et al. Crystal structure, infrared spectra, and microwave dielectric properties of the $\mathrm{EuNbO}_{4}$ ceramic. Ceram Int 2021, 47: 4321-4326.

[33] Li JM, Zhang CM, Liu H, et al. Structure, morphology, and microwave dielectric properties of $\mathrm{SmAlO}_{3}$ synthesized by stearic acid route. $J A d v$ Ceram 2020, 9: 558-566.

Open Access This article is licensed under a Creative Commons Attribution 4.0 International License, which permits use, sharing, adaptation, distribution and reproduction in any medium or format, as long as you give appropriate credit to the original author(s) and the source, provide a link to the Creative Commons licence, and indicate if changes were made.

The images or other third party material in this article are included in the article's Creative Commons licence, unless indicated otherwise in a credit line to the material. If material is not included in the article's Creative Commons licence and your intended use is not permitted by statutory regulation or exceeds the permitted use, you will need to obtain permission directly from the copyright holder.

To view a copy of this licence, visit http://creativecommons. org/licenses/by/4.0/. 